Among the subjects of addresses and discussions were: New patterns of self-government in the Gold Coast and Nigeria; Federal Union in British Central Africa; Citizenship in Portuguese Africa; Social change in the Belgian Congo; Economic and social development plans for the Belgian Congo and Ruanda; The current situation in French Tropical Africa; Relations between government and missions, and religious group conflicts.

\title{
Rhodes-Livingstone Institute
}

A CONFERENCE of research officers was held at the new Institute buildings in Lusaka from 4 to 10 January 1953 ; in addition to the Director (Dr. J. C. Mitchell) and the research officers of the Institute, Professor and Mrs. Kuper of Natal University attended in an advisory capacity; Mr. R. Moffat, Urban Native Courts Adviser, Northern Rhodesia Government, with his assistant Mr. A. Mwenya, and Mr. J. Good, psychologist to the European Education Department, Northern Rhodesia Government, made occasional visits.

Dr. Mitchell discussed tribal dances as a feature in African urban life, and in particular the Kalela in which all the participants wear European dress; Dr. Mitchell suggested that dances of this type reflected the social situation in the Copperbelt and represented the acting out of a phantasy in which the dancers enjoyed the prestige of European rank. It appeared that on the Copperbelt a system of social classes was beginning to develop, although tribalism was still an important social category. Other subjects of discussion, arising from reports by research fellows, were: the political organization of the Mambwe; native administration in urban areas; effects of labour migration among the Lakeside Tonga (among these people also the high prestige placed on European clothing can be illustrated by the Malipenga dance); Kaonde village structure, in which proximate generations are spatially separated by the siting of huts; proposals for research among the Herero. Mr. Good contributed an account of projective tests and the possibility of their use by anthropologists in the field. The difficulties encountered in urban surveys-particularly resistance on the part of persons interviewed-were described by Mr. Katilungu.

\section{Social Science Conference in Uganda}

A SECOND joint meeting between the social scientists attached to I.R.S.A.C. (Institut de Recherche Scientifique en Afrique Centrale) and to the E.A.I.S.R. (East African Institute of Social Research) was held at the headquarters of the E.A.I.S.R., Makerere College, Kampala, from 23 to 28 February i953.

The conference was attended by I I anthropologists, 3 linguists, 2 economists, and 2 psychologists. Some members of a committee of social experts called by the C.S.A. (Council for Scientific Research in Africa South of the Sahara) which was meeting at Kampala subsequently, also attended as observers. They included Professor Marcel Griaule and M. le Gouverneur Deschamps (France); Dr. Clyde Mitchell (Northern Rhodesia); Professor Santa Rita (Portugal); Mr. R. H. Sutton and Professor Monica Wilson (Union of South Africa); together with Mrs. Chilver (Colonial Office) and Professor E. Franklin Frazier (Social Science Division of UNESCO).

The conference began with a public session opened by H.E. the Governor of Uganda, when reports on the work of I.R.S.A.C. were read by Professor L. van den Berghe (Director) and Dr. J. J. Maquet; and on the work of the E.A.I.S.R. by Dr. A. I. Richards (Director). Reports on personnel research and sociological research in South Africa were read by Mr. R. H. Sutton and Professor Monica Wilson respectively, and on the work of the RhodesLivingstone Institute by Dr. Clyde Mitchell.

At the subsequent working sessions of the conference, papers were read in the following 
order: Mr. W. H. Whiteley (E.A.I.S.R.) 'The Sentence and Sociology' and M. Coupez (I.R.S.A.C.) 'Le système tonal et les verbes en kinyarwanda et kirundi'; Dr. V. Neesen (I.R.S.A.C.) 'Le premier recensement par échantillonnage au Ruanda-Urundi en 1952' and Mrs. P. Reining (E.A.I.S.R.) 'Survey technique; the Bukoba survey'; Dr. A. W. Southall (E.A.I.S.R.) 'The study of social differentiation in Kampala' and Mr. H. S. Morris (E.A.I.S.R.) 'The structure of the Indian community in Kampala'; Dr. J. J. Maquet (I.R.S.A.C.) 'The cultural values of Ruanda' and Dr. E. H. Winter (E.A.I.S.R.) 'Life histories as a research tool'; Mr. A. B. Mukwaya (E.A.I.S.R.) 'Some problems of land tenure in Buganda' and Mr. J. Beattie 'The kibanja system of land tenure in Bunyoro'; M. D. Biebuyck (I.R.S.A.C.) 'Maternal uncles and sororal nephews among the Balega' and Dr. J. J. Maquet 'The Ruanda premise of inequality'; Mr. C. C. Wrigley (E.A.I.S.R.) 'African farming in Buganda' and Dr. A. W. Southall 'Belgian and British Administration in Alurland'; M. D. Biebuyck 'Exchanges taking place before, during, and after initiations to the Bwami association' and Mr. C. Reining 'The Zande settlement scheme'.

\section{African Studies at Boston University}

ON I July I953 an African Research and Studies Programme was formally inaugurated at Boston University. It is to be attached to the Boston University Graduate School and is under the direction of Dr. William O. Brown, Professor in the Department of Sociology and Anthropology, formerly Chief of the African Research Branch in the Department of State, Washington. The programme is designed to make a contribution to basic research and studies in the field of African affairs, and emphasis will be laid on the fundamental analysis of economic, social, political and technical factors as they relate to social change in contemporary Africa. Close liaison will be maintained with individual scholars and research organizations in the United States, Europe, and Africa.

Dr. Brown has long been a member, and a valued friend, of this Institute, and we welcome his appointment with its promise of fruitful collaboration between the new centre and the International African Institute in this important field of studies.

\section{Margaret Wrong Prize: Result of 1952 Competition}

THrs competition was open to competitors from Northern and Southern Rhodesia, Nyasaland, Portuguese East Africa, and Angola. The Silver Medal and prize of $£, s$ have been awarded to Oscar Ribas of Luanda, Angola, for a story in Portuguese entitled $A$ Praga.

For the 1953 competition manuscripts are invited from the Union of South Africa, the High Commission Territories and Madagascar. The language may be English, Afrikaans or French and manuscripts should reach the London office of the International Committee on Christian Literature for Africa, 2 Eaton Gate, London, S.W. I, before 31 December 1953.

\section{Recording Vernacular Languages in Nigeria}

Dr. HANS WOLFF, an American linguistic specialist, is travelling for twelve months in Nigeria under the auspices of UNESCO, in order to study and advise on the use of vernacular languages in education and literacy campaigns. Dr. Wolff is proposing to record little-known languages and devise orthographies for those not yet reduced to writing. 